\title{
Joint Inflammation: Insights of Osteoarthritis, Gouty and Rheumatoid Arthritis and its Prevalence, Mechanism, Medications and Remedies
}

\author{
R. KATTURAJAN AND EVAN PRINCE SABINA* \\ Department of Biomedical Sciences, School of Biosciences and Technology, Vellore Institute of Technology, Vellore, Tamil \\ Nadu 632014, India
}

\section{Katturajan et al.: Joint Inflammation Factors and Remedies}

\begin{abstract}
Arthritis is a chronic inflammation in joints, which mostly affects the bones. In the global prevalence of joint inflammation, it's means to be taken it as potential issues. Current treatments mostly targeting the inflammatory cytokines or effector molecules and oxidative stress involved in arthritis as pain relief temporarily. This review has mechanistically demonstrated the type of joint inflammation insights in to arthritis, such as osteoarthritis, gouty arthritis and rheumatoid arthritis to understand the clear background. This review has also highlighted the prevalence, mechanism and mediations used for arthritis, in which various causative agents are used to induce arthritis in preclinical studies that has been collectively elucidated. This review is first to be reported the mechanism of various arthritis causative agents. It pointed out the side effects of clinical medicine used for arthritis and suggested the natural products involved in medication for above-listed conditions. As comparatively natural products are low cost, easily available and beneficial than modern medicines with minimal side effects.
\end{abstract}

Key words: Joint inflammation, osteoarthritis, gouty arthritis, rheumatoid arthritis, natural therapeutics

Arthritis is an inflammation in joints; this term includes over 100 disorders related to the bones and its joints. It is associated with the joint in fingers, hips, wrists and knees $^{[1]}$. The rate of this condition is increasing due to lifestyles and prominent to the aged people. Thus 1 out of 5 mankind was found to be in this disease. It can be caused due to age, genes, gender, injuries in joints and obesity. Some of the rare types of arthritis inflammation can be seen in organs, connective tissues and skins ${ }^{[2]}$. To overcome this condition as a primary defense the medications such as acetophenone, Nonsteroidal Antiinflammatory Drugs (NSAIDs), corticosteroids and anti-rheumatic agents are prescribing for temporary relief as well these agents reported to have various side effects $^{[3-5]}$. Therapeutics to get rid of joint inflammation with minimal or no side effects are to be discovered. Few standard organizations have proved that many countries have been following their ancient traditional ways as natural therapeutics and treating many diseases including joint inflammation ${ }^{[6]}$. Natural therapeutics of preclinical experiments on various joint inflammation conditions such as osteoarthritis, gouty and rheumatoid arthritis have also been discussed in this review.
In summary, fig. 1 describing the overview of joint inflammation clinical indications and their treatments. In brief, the occurrence of joint inflammation leading to cartilage destruction and synovium stimulation. As well, oxidative stress and inflammatory system are playing a significant role in this condition by activating $\mathrm{T}$ cells and inflammatory mediators such as cytokines and chemokines. Several medications are prescribed to inhibit $\mathrm{T}$ cell and oxidative stress from reducing inflammation. However, prolonged exposure leads to adverse effects, so present research on reducing inflammation without side effects with natural products is studying preclinically. This is the review of various agents to induce joint inflammation and protocol and mechanism collectively in preclinical studies and natural remedies against it.

This is an open access article distributed under the terms of the Creative Commons Attribution-NonCommercial-ShareAlike 3.0 License, which allows others to remix, tweak, and build upon the work non-commercially, as long as the author is credited and the new creations are licensed under the identical terms

Accepted 01 September 2021

Revised 14 June 2021

Received 18 January 2021

Indian J Pharm Sci 2021;83(5):886-898 


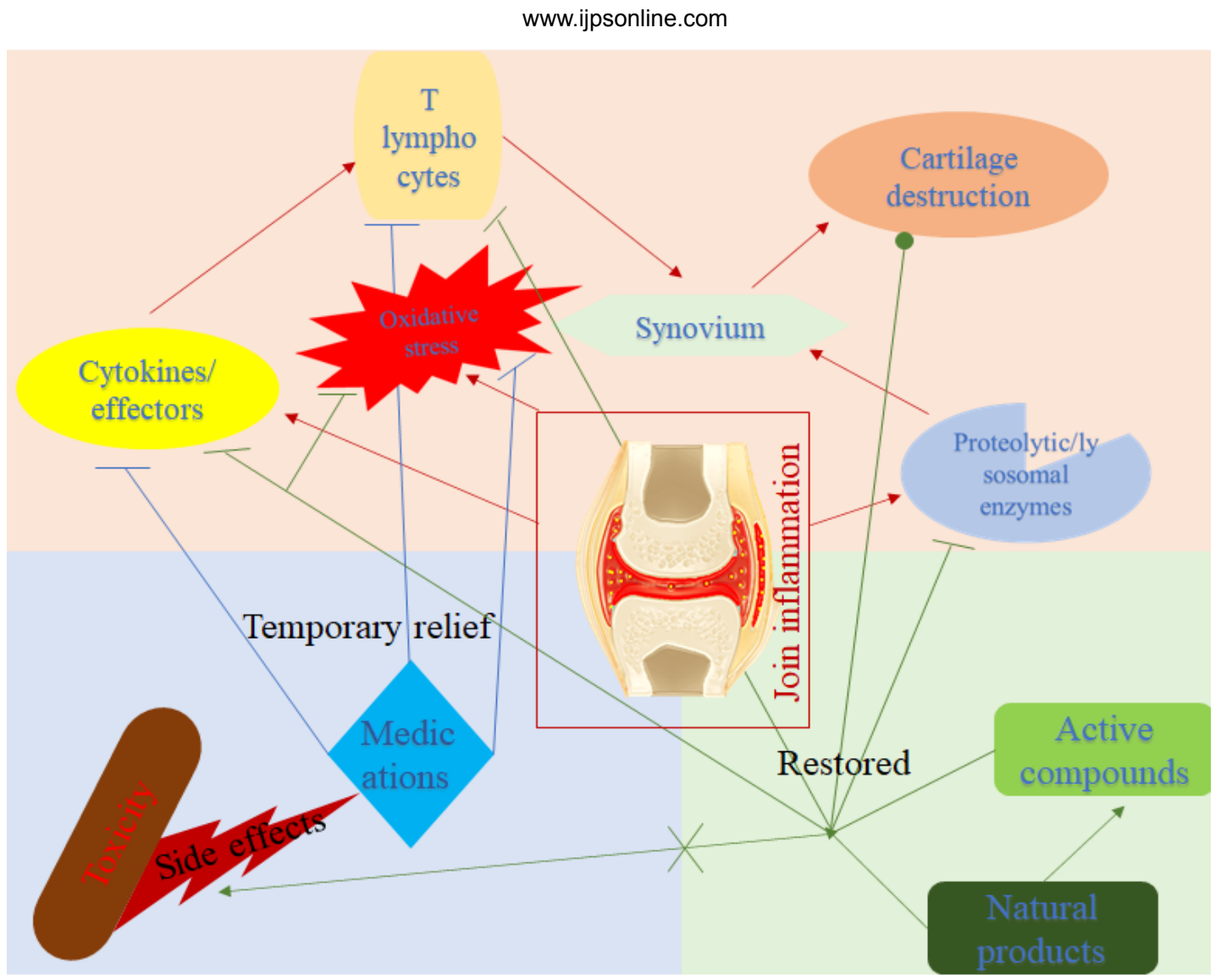

Fig. 1: Overview of joint inflammation clinical indications and its treatments

Note: Brown line indicating the findings during inflammation in joints; blue line indicating action of mechanism of chemical or synthetic medications actions and its side effects; green line indicating the potential activity on inflammation in joints and its restoring mechanism

\section{OSTEOARTHRITIS}

Osteoarthritis is generally an articular cartilage disease found in articulation organ systems like a capsule, ligaments, menisci, periarticular muscle and synovium $^{[7]}$. Joint in our body can be classified into patellofemoral and tibiofemoral, where osteoarthritis occurs either of this joint, but most of the research has been studied in the patellofemoral joint because it is highly observed ${ }^{[8]}$. It causes joint inflammation, changes in cartilage structure and alters the anti-inflammatory and pro-inflammatory mechanisms ${ }^{[9]}$. The risk factors include age, weight, gender, muscle weakness, obesity and repetitive movement of joints leads to trauma ${ }^{[10]}$. The disease such as cancer, cardiovascular disease and diabetes are also associated with osteoarthritis.

\section{Prevalence:}

A recent study has been reported that the National Health Interview Survey appraised approximately 1.4 crore people in the United States of America who were found to have an osteoarthritis symptom. Where 0.7 crore of the affected people seemed to be less than $65 \mathrm{y}$ ${ }^{[11]}$. In Greece, it was found that the prevalence rose up to
$6 \%$. In osteoarthritis, women are more prominent than man where prevalence has raised from $3.7 \%$ to $26.7 \%$ around the globe ${ }^{[10]}$. Prevalence in India has reported that the rate of osteoarthritis raised to $39 \%$, where $45 \%$ of the women in India have this symptom over $65 \mathrm{y}$ of age ${ }^{[12]}$. The Johnston country osteoarthritis project has reported that the African-American population and the other people such as Irish, Italian, Lebanese, German, Moroccan and Asian have an osteoarthritis prevalence of $28 \%{ }^{[13]}$.

\section{Mechanism:}

In a normal joint, the bones are enclosed or covered by cartilage shielded by capsules associated with a synovial membrane that generates synovium ${ }^{[14]}$. The integration of the capsule and synovium protects the cartilage and connective tissues in the bone. In case of aged or aberrant mechanical force that induce a chondrocyte from a lower metabolic activity which stimulates inflammatory mediators that produce macrophages during inflammation which includes cytokines and chemokines like Interleukins (IL) such as IL-1, IL-6, IL-8, IL-17 and IL-18, Monocyte Chemotactic Protein 1 (MCP-1), Differentiation-Inducing Factor (DIA), 
growth-related oncogene and onco-statin-M will also generate Reactive Oxygen Species (ROS) such as Nitric oxide (NO), Oxygen $\left(\mathrm{O}_{2}\right)$, Hydrogen peroxide $\left(\mathrm{H}_{2} \mathrm{O}_{2}\right)$ and Peroxynitrite (ONOO-) ${ }^{[15]}$. In addition, lipid inflammatory mediators like Prostaglandin (PG) and Leukotrienes (LT) rise due to the chondrocyte metabolism that leads to the release of proteolytic enzymes that alters the normal structural formation of joints by increasing the synovium and fragmentation of cartilage that lead to pain and immobility in osteoarthritis condition $^{[16]}$.

\section{Chemical induced osteoarthritis:}

Papain: It is a proteolytic enzyme that is commercially available. It is used as osteoarthritis-inducing agent papain that needs to be injected with cysteine to cause osteoarthritis. The cysteine act as a papain activator. To cause osteoarthritis, $4 \%$ of the papain prepared with $0.03 \mathrm{M}$ of cysteine and can be injected in intraarticular joint ${ }^{[17]}$. Inducing papain in an intra-articular joint increases the joint volume and knee distension. When papain administrated into the cartilage, it releases chondroitin sulphate which breakdown and induces the production of inflammatory cytokines such as IL-beta $(\beta)$ and Tumor Necrosis Factor Alpha (TNF- $\alpha$ ) as well as LT; these cytokines increase the matrix metalloproteinases level ${ }^{[18,19]}$. The role of the matrix metalloproteinases is to degrade matrix protein in organogenesis, but in osteoarthritis condition, it increases the level of degradation of matrix protein, leading to the formation of a ROS such as $\mathrm{NO}^{[20]}$. These all together show a symptom of osteoarthritis.

Monosodium Iodoacetate (MIA): It is a commercially available product. To cause an osteoarthritis, $3 \mathrm{mg} /$ $\mathrm{kg}$ body weight of MIA can be dissolved in the sterile saline and injected into the articular cartilage of the joint ${ }^{[21,22]}$. Inducing MIA in articular space in animal causes joint inflammation, which is similar to the human osteoarthritis. Where full mechanism of MIAinduced osteoarthritis yet to be studied but when MIA is induced, an inflammation will form, which leads to degenerative structural changes in articular cartilage, decrease the weight, increases the pro-inflammatory cytokines like IL-1, IL-6, TNF- $\alpha$, Prostaglandin-E2 (PGE2) and genetic erosion of Transient Receptor Potential Ankyrin 1 (TRPA1) ${ }^{[9,23,24]}$. One of MIA's actions has been found that it inhibits the glyceraldehyde-3phosphate dehydrogenase by inducing the formation of ROS and caspase stimulation ${ }^{[25]}$. Caspase belongs to the family of a proteolytic enzyme, which is responsible for inflammation ${ }^{[26]}$.
Collagenase type 2: It is commercially available, which was dissolved in sterile saline. It can be injected intra-articularly to the leg joint to cause osteoarthritis. Collagenase can be injected twice in a day ${ }^{[27]}$. Collagenase is a protein degradation enzyme that degrades the protein called collagen. When collagenase is injected to intra-articular space, it leads to the degradation of the collagen layer which is surrounded around cartilage. Due to the collagen layer's degradation, the cartilage structure will be changed that also increase the levels of synovium and degrade the proteoglycan of the cellular matrix ${ }^{[28]}$. Proteoglycans consist of protein that cores with glycosaminoglycan chains, whereas glycosaminoglycan can be found in synovium in osteoarthritis condition ${ }^{[29]}$.

\section{Medication for osteoarthritis:}

The first line of medication prescribing for osteoarthritis is acetaminophen, which is also known as paracetamol; at a mild stage due to its antipyretics and analgesic properties ${ }^{[30]}$. The mechanism of this drug against osteoarthritis is yet to be studied. Due to the absence of anti-inflammatory activity and also it causes hepatotoxicity ${ }^{[31]}$. NSAIDs such as diclofenac, celecoxib, ibuprofen, ketoprofen and naproxen were used to prescribe. The NSAID mechanism against osteoarthritis is to inhibit the prostaglandin isoenzymes like Cyclooxygenase 1 (COX1) and COX2 where COX1 inhibition causes gastro-toxicity so COX2 selective NSAID were used. COX2 enzyme are used to be highly expressed in inflammation conditions ${ }^{[32]}$. NSAIDs have analgesic, antipyretic and antiinflammatory activity with the COX2 inhibition ability which is used against osteoarthritis. Even though NSAIDs reduce the osteoarthritis inflammation, it is not advisable to take due to its severe side-effects like hepatotoxicity, renal-toxicity, gastrointestinal-toxicity and cardiovascular disorders consuming for long term or on overdosage ${ }^{[33]}$.

Corticosteroids also suggested for the treatment of osteoarthritis because of its immunosuppressive and anti-inflammatory properties. Betamethasone, dexamethasone, methylprednisolone and triamcinolone were used for the treatment. The mechanism is to act on steroid hormone receptor to inhibit the inflammation by the reduction of microvascular permeability to prevent the inflammatory cells from accumulation and stimulation of neutrophils to inhibit the production of $\mathrm{PG}$ and $\mathrm{LT}^{[34,35]}$. Certain research has reported that corticosteroids have many side effects, such as 
skin disease, cushing syndrome, ophthalmologic, cardiovascular disease, neurotoxicity, gastro toxicity and poor growth ${ }^{[3,4]}$.

In addition, opioid analgesics like tramadol and oxycodone were commonly used for treating osteoarthritis. When the patient takes opioid analgesics, it binds with the opioid receptor in the central and peripheral nervous system, which inhibits the nociceptive pathway of pain ${ }^{[36]}$. This medication also shows the side effect, for example, gastrointestinal diseases, skin diseases, neurotoxicity and autonomic nervous system disorder ${ }^{[37]}$.

\section{GOUTY ARTHRITIS}

Gouty arthritis is a disorder called as unwalkable disease where the uric acid level in the serum seems to be increased in this condition ${ }^{[38]}$. Gout is a type of arthritis that causes inflammation in joints of the toe, elbow, ankles, fingers and knees with indications of tender, hot, red and swollen in joints. Which is due to the diet, heredity combinations and raised level of urate in serum ${ }^{[39,40]}$. Risk factors that cause gout are age (40$50 \mathrm{y}$ ), medications (such as aspirin, levodopa, niacin, etc.,) alcohol intake, lead exposure, obesity, high blood pressure, diabetes, hypothyroidism, hypertension, cancer and kidney disease ${ }^{[41,42]}$. There are some diseases associated with gout are type- 2 diabetes, hyperuricemia, hypertension and Cardiovascular Disease (CVD) ${ }^{[43]}$. Reasons behind the gout increase are the lacking of common habits like diet, exercises, obesity and metabolic syndromes such as cardiovascular disease, diabetes and ischemic stroke ${ }^{[44]}$.

\section{Prevalence:}

A recent study has reported that $4-6 \%$ of men and approximately $2 \%$ of women are affected by gouty arthritis in western countries such as Europe, United States, Canada, Australia and England. Commonly it occurs $1-3 \%$ of the common people and men are more frequently affected than women. It is evident from the recent literature which an increase in prevalence in that the percentage exceeded up to $10 \%$ for males and $6 \%$ for females in many countries ${ }^{[44]}$. Other countries like Germany, USA, Europe, Switzer land, Australia, Israel, South Korea, Japan and Canada it ranges from $6 \%$ to $10 \%$. This is because of less diet, food habitat, obesity due to no utilization of exercises and syndrome $\mathrm{X}^{[45]}$.

\section{Mechanism:}

Gouty arthritis can be caused by various factors where the mechanism is when the uric acid level in our blood increased due to the obesity of other factors that is need to be filtered and excreted through the kidney by the enzyme called uricase ${ }^{[46]}$. The excess level of uric acid in the blood cannot be completely excreted; in that case, the uric acid further increases and settles in renal tissues and joints and later forms a crystal called uric acid. That crystal interacts with the phagocytic cells and induces pro-inflammatory cytokines release, which will release macrophages ${ }^{[47]}$. Microcrystal infiltration in synovial membrane will also induce leukocytes to lyse the lysosomal membrane and oozed out of lysosomal enzymes into the blood. PG and LT get raised and lead to the formation of $\operatorname{ROS}^{[40]}$.

\section{Chemical induced gouty arthritis:}

Monosodium urate (MSU): MSU crystals can be synthesized by mixing with the $4 \mathrm{~g}$ of uric acid in $800 \mathrm{ml}$ of water and $9 \mathrm{ml}$ of $0.5 \mathrm{~N}$ sodium hydroxide. The mixture should be adjusted to a $\mathrm{pH}$ of 8.9 and heated in a water bath at $60^{\circ}$; later it should be cooled overnight under cold temperature, then washed and dried the mixture compounds ${ }^{[48]}$. At last, needle-like MSU crystals can be seen under the microscope that can be used to induce gouty arthritis. When MSU is injected into the paw, it simulates the neutrophils and macrophages and produces cytokines such as IL-1 $\beta$, IL-6, IL-8, IL-18 and TNF- $\alpha^{[49]}$. Increased levels of neutrophils will influx into synovial fluids. Accumulation of a large amount of synovial fluid will lead to ROS formation and lyse lysosomal membrane to release lysosomal enzymes ${ }^{[50]}$. Thus, in gouty arthritis patients, the lysosomal enzymes are found to be excess levels.

\section{Medication for gouty arthritis:}

The most common drugs prescribed for gouty arthritis are in their following ways against the inflammation like Colchicine block the generation of LTB4, Corticosteroids drug acts against inflammation through Adrenocorticotropic Hormone (ACTH) and NSAID such as indomethacin, ibuprofen, naproxen and sulindac has analgesic, antipyretic and anti-inflammatory medical property ${ }^{[5]}$. Even though these drugs are used to treat gouty arthritis, it also has severe side effects such as chronic kidney diseases, gastrointestinal toxicity and high Blood Pressure (BP) upon abiding consumption ${ }^{[51]}$. Allopurinol, febuxostat, probenecid and benzbromarone are the xanthine oxidase inhibitors which have the property of uricosuric agent and used as a treatment for gouty arthritis. These drugs are also reported to have 
side effects such as hypersensitivity arthralgia, nausea, diarrhea, gastric-ulcer and gastrointestinal-toxicity ${ }^{[49,52]}$.

\section{RHEUMATOID ARTHRITIS}

Rheumatoid arthritis is a disease associated with joints commonly called an autoimmune inflammatory disease that leads to structural changes in multiple joints where the feet and hand joints are the first affected part and later other parts of the body are affected, resulting in severe pain and immobility ${ }^{[53]}$. As a result of structural changes in joints it causes erosions in bone and degradation of cartilage ${ }^{[54]}$. This induces macrophages and neutrophils to release cytokines like IL-1 $\beta$, IL-6, IL-17 and TNF- $\alpha$, leading to the destruction of joints' pleiotropic traits rheumatoid arthritis ${ }^{[5]}$. It also causes the reduction of red blood cells in the blood, inflammation in the lungs and heart ${ }^{[56]}$. Common factors causing rheumatoid arthritis are age, sex, race, poverty, chain-smoking, alcohol consumption and obesity, where the diseases associate with rheumatoid arthritis are CVD, atrial fibrillation, stroke and autoimmune diseases ${ }^{[57,58]}$.

\section{Prevalence:}

The report of the Rochester Epidemiology Project has said that the prevalence rate of rheumatoid arthritis has increased from $4 \%$ to $5.3 \%$ in the United States. Where also, among the 1 million people, 531 women and 277 men are affected by this disorder. People above $65 \mathrm{y}$ old are more prominent than the adults, where 894 aged people are affected in 1 million population ${ }^{[59]}$. The rate of rheumatoid prevalence is increasing every year of $2.5 \%$ of women and $2 \%$ of men. Other countries like Denmark, Finland, Sweden and Norway the prevalence rate of rheumatoid arthritis has been increased from 200 to 500 people in 1 million population ${ }^{[60,61]}$. In addition, the Global Burden of the disease has also reported that the prevalence of rheumatoid arthritis that been increased from $0.5 \%$ to $1.1 \%$ globally. In Southern European countries, the prevalence rate increases from $0.3 \%$ to $0.7 \%$ and in many developing countries, prevalence is not exact but approximately increased from $0.1 \%$ to $0.5 \%$ reported by the American College of rheumatology ${ }^{[62]}$.

\section{Mechanism:}

The people with rheumatoid arthritis seem to have an increased C-Reactive Peptide (CRP) in the blood ${ }^{[63]}$. Anticitrullinated-Protein Antibodies (ACPA) and Peptidyl-Arginine-Deiminase (PAD) enzyme are responsible for causing rheumatoid arthritis. Among that ACPA, it is associated with the genetics where abnormal antibody glycosylation can be found in rheumatoid arthritis condition that induces the inflammation in joints ${ }^{[64]}$. During inflammation, activated T-lymphocytes enter into synovium, leading to aggregation of CD4 and infiltration of CD8 cells. These induce the dendritic cells by major histocompatibility complex-2 molecules expression, which stimulates the immune response in the joint tissues ${ }^{[65,66]}$. This leads to thickening of the synovium, erosion of cartilage, the disintegration of bone and joint. The TRANCE receptor induces the production of osteoclast in the inflammation responsible for joint degradation. TNF- $\alpha$ is a major factor in rheumatoid arthritis where it is released when rheumatoid factor (ACPA) is formed were also TNF is stimulated by IL-17 in the hypersensitivity condition ${ }^{[67]}$. The role of PAD is to convert arginine to citrulline where type 4 PAD inhibition was encoded by a gene called PADI-4 which is also responsible for the rheumatoid arthritis ${ }^{[68]}$.

\section{Chemical induced rheumatoid arthritis:}

Collagen type-2: Collagen type-2 and Incomplete Freund's adjuvant (IFA) are commercially available. Collagen type- 2 should be dissolved in $0.05 \mathrm{M}$ acetic acid and mixed with IFA. Here IFA is used to stabilize the collagen. As administrated to rats, the mixture can be injected intradermally at the rat's tail. This admiration causes rheumatoid arthritis, which can be boosted up on the $10^{\text {th }} \mathrm{d}$ by the mixture administration subcutaneously in the tail ${ }^{[69,70]}$. Collagen mixture is injected; it initiates the immune response against collagen with $\mathrm{T}$ and B-cells' activation that produces antibodies (predominately IgG2). This antibody targets the collagen and stimulates the autoimmune response against collagen by producing macrophages, neutrophils and lymphocytes to the joint ${ }^{[71]}$. In addition, the immune response leads to the activation of inflammatory mediators and cytokines such as TNF- $\alpha$, $1 \mathrm{~L}-10$ and $1 \mathrm{~L}-23$ and Th-17 ${ }^{[70]}$.

Freund's complete adjuvant (FCA): It is commercially available where adjuvant contains heat-killed Mycobacterium tuberculosis, which was suspended in paraffin oil. As administration in rats, the adjuvants can be injected intradermally on the rat's paw. Rheumatoid arthritis are caused by the adjuvant in $18 \mathrm{~d}^{[72,73]}$. Adjuvant is injected intradermally; it causes inflammation in joints with the generation of synovial cells that induces the immunoinflammatory cells to cartilage destruction in joints. Due to the increased level of synovial cells, the neutrophils and macrophages stimulated that lead 
to the formation of ROS like $\mathrm{O}_{2}, \mathrm{H}_{2} \mathrm{O}_{2}$ and $\mathrm{OH}^{-}$. ROS generally damage the tissues and protein membranes; when it is damaged, the lipid membrane will result in lipid peroxidation and initiates NO that destruct the joints ${ }^{[74]}$. As pro-inflammatory cytokines have been released during joint destruction, the increased levels of cytokines are responsible for inflammation such as TNF- $\alpha$ and IL- 6 released in joints, leading to the initiation of the leukocytes ROS formation, that result in cartilage damage ${ }^{[75,76]}$. In addition, inflammatory mediators like PG and LT are generated.

Pristane oil: It is commercially available, which also can be used to cause rheumatoid arthritis. Pristane can be injected via intraperitoneally. On the $7^{\text {th }} \mathrm{d}$, pristane can be again injected to increase the inflammation ${ }^{[77,78]}$. Mechanisms of pristane inducing rheumatoid arthritis are not known, but the pristane initiates an autoimmune response by activating immune to antigens to prevent microbes. Antibodies and collagens are used to detect rheumatoid arthritis, which is similar to pristaneinduced arthritis. Thus, rheumatoid arthritis represents bone erosion, cartilage damage and joint inflammation. These factors were confirmed in the pristane induction in model ${ }^{[79]}$.

Peptidoglycan-polysaccharides: Peptidoglycanpolysaccharides of the Streptococcus Cell Wall (SCW) are commercially available where the peptidoglycanpolysaccharides were from Streptococcus pyogenes. SCW can be dissolved in PBS and injected intraarticularly on the ankle joint to induce rheumatoid $\operatorname{arthritis}^{[80,81]}$. SCW-induced arthritis is a state of rheumatoid arthritis with the infiltration of granulocyte, CD4-T cells and macrophages in the synovium, which leads to cartilage erosion and bone disintegrations. It also induces cytokines and chemokines like TNF- $\alpha$, IL-4, IL-1 $\alpha$, Vascular Cell Adhesion Molecule-1 (VAM-1) and MCP-1. In addition, it is involved in NOS and $\mathrm{COX}$ in the $\mathrm{SCW}$-induced arthritis development has been reported ${ }^{[82]}$.

\section{Medication for rheumatoid arthritis:}

NSAIDs like ibuprofen and naproxen are used to treat rheumatoid arthritis due to its anti-inflammatory and analgesic properties. Mechanisms of NSAIDs against rheumatoid arthritis have the ability to prevent the PG production and mainly inhibition of $\mathrm{COX}^{[83]}$. Even though it has anti-inflammatory activities, it is not advisable to take due to its severe side effects such as gastrointestinal bleeding, high blood pressure, antihypertensive, renal toxicity, hepatotoxicity and $\mathrm{CDV}^{[33]}$.
Corticosteroids like prednisone, triamcinolone and dexamethasone were used to reduce the joints pain. Cortisol is a hormone produced in our body in the adrenal gland where the role corticosteroids is to reduce the immune response that results in an inflammation reduction $^{[84]}$. In addition, steroid hormones are administrated to reduce rheumatoid arthritis that acts as immune-modulators to suppress the formation of antibodies during inflammation. Immune modulators are the inhibitors of the immune system ${ }^{[85]}$. Where corticosteroids are also not advisable to take due to its major side effects like vasoconstrictive effects, asthma, nausea, pulmonary edema and autoimmune diseases were also causes Sjogren syndrome, graves ophthalmopathy and osteoarthritis while consuming long-term ${ }^{[3,86]}$.

Disease-Modifying Antirheumatic Drugs (DMARDs) like methotrexate, leflunomide, hydroxychloroquine and sulfasalazine were used to treat rheumatoid arthritis. The mechanism of DMARD is to initiate the adenosine hormone to neutrophil reduction, LTB4 inhibition produced by neutrophils ${ }^{[87]}$. It also reduces the level of pro-inflammatory cytokines such as IL-1, IL-6, IL-8 and inhibited the collagenase expression in synovium to terminate inflammation in joints ${ }^{[88]}$. In addition, it inhibits autoimmune responses like malfunction of lymphocytes, T-cell activation and B-cell activators ${ }^{[89]}$. DMARD are powerful drugs it causes side effects like stomach upset, gastro-toxicity, bone marrow erosion, lung disease, hepatotoxicity, neurotoxicity and liver disease $^{[90]}$, so it's better to stop consuming this drug.

\section{NATURAL PRODUCTS}

World Health Organization (WHO) has been reported that $75 \%$ of people in global of developing countries are dependent on ancient traditional medicines like Ayurveda, Ebers Papyrus, Hippocrates and Chinese herbal medicine ${ }^{[6]}$. These medicines have been followed as more than $1000 \mathrm{y}$ due to its beneficial role and treatment against diverse disorders in humans and animals ${ }^{[91,92]}$. Natural therapies are treating the diseases based on their bioactive compounds in it. That is also called as flavonoids or phytochemicals or polyphenols ${ }^{[3]}$. Polyphenols are the naturally derived-valuable compounds that have been reported that it has wide medicinal properties like antioxidant, antimicrobial and anti-inflammatory abilities ${ }^{[94,95]}$. ROS is the formation of a group of free radicals, which plays a serious role in inflammation or diseases, by scavenging the free radicals can prevent ROS. To scavenge the free radicals, antioxidants need to be high where herbal 
products with polyphenols have been reported to be rich in antioxidants ${ }^{[96]}$. As comparatively natural products are less costly and beneficial than modern medicines with lots of side effects ${ }^{[97]}$. Moreover, a mechanism of actions of some of natural therapeutics on joint inflammation conditions such as osteoarthritis, gouty and rheumatoid arthritis are listed in Table 1-Table 3.

Reports from the previous experimental studies show natural products against osteoarthritis, gouty and rheumatoid arthritis are potent to have beneficial effects. The effect of natural therapeutics against osteoarthritis includes Honokiol, a compound of Magnolia officinalis barks, which has antiarthritic activity by inhibiting $\mathrm{T}$ cell production and preventing NO production protects chondrocytes ${ }^{[98]}$. Curcumin has low solubility, so phosphatidycholine has been mixed in the ratio of $1: 2$, Anemonin, a compound of Ranunculus eschscholtzii Alpha-mangosteens, had restored inflammation by Nuclear Factor- $\kappa \mathrm{B}(\mathrm{NF}-\kappa \mathrm{B})$ pathway ${ }^{[99-101]}$. SKI-306X, a combination of Clematis mandshurica, Prunella vulgaris, Trichosanthes kirilowii in the ratio of 1:2:1 and mud of Lake Urmia found to have a better effect on arthritis patients ${ }^{[102,103]}$. A dietary supplement has scavenged the free radicals and protects Deoxyribonucleic acid (DNA) by joints restoration $^{[104]}$. Aucubin and Salvianolic acid-Bis shows good anti-inflammatory by inhibiting the p65 nuclear translocation-signaling pathway ${ }^{[105-107]}$.

The effect of natural therapeutics against gouty arthritis as follows, an effective antioxidant and antibiotic product, turmeric and Pistacia integerrima leaf extract, has restored MSU-induced gout in mice, enhancing xanthine oxidase inhibitor or inhibited purine metabolism ${ }^{[108]}$. Sparattosperma leucanthum and Tabebuia roseoalba have proven a paw volume reduction in $72 \mathrm{~h}$, protected the synovial cell from the damage and reduces the serum uric acid level in gout mice ${ }^{[109,110]}$. Sunflower head powder recovered the synovium deformation and cell

TABLE 1: ANTIARTHRITIC ACTIVITY OF NATURAL THERAPEUTICS ON OSTEOARTHRITIS AT CLINICAL/ PRECLINICAL STUDIES

\begin{tabular}{|c|c|c|c|c|c|}
\hline Therapeutics & Source & Formulation & $\begin{array}{l}\text { Causative } \\
\text { agent/Model }\end{array}$ & Therapeutic effects & Reference \\
\hline Honokiol & Magnolia officanalis & $\begin{array}{l}\text { Aqueous } \\
\text { solution }\end{array}$ & NA/Patients & $\begin{array}{l}\text { Inhibition of COX2, PGE2 and IL } \\
\text { signaling }\end{array}$ & [98] \\
\hline Curcumin & Etlingera elatior & $\begin{array}{l}\text { Curcumin in } \\
\text { aqueous pho- } \\
\text { phatidycholine }\end{array}$ & NA/Patients & $\begin{array}{c}\text { Protects the degradation of } \\
\text { chondrocytes and proteoglycan and } \\
\text { prevents (AP)-1, IL-1B and NF-K }\end{array}$ & [99] \\
\hline SKI-306X & $\begin{array}{c}\text { Clematis } \\
\text { mandshurica; } \\
\text { Prunella vulgaris; } \\
\text { Trichosanthes } \\
\text { kirilowii }\end{array}$ & $\begin{array}{c}\text { Aqueous with } \\
\text { the ratio of } \\
1: 2: 1\end{array}$ & $\begin{array}{l}\text { Collagenas/ } \\
\text { Rabbit }\end{array}$ & $\begin{array}{l}\text { Inhibited proteoglycan degradation, } \\
\text { glycosaminoglycan releases and } \\
\text { structural changes in cartilage }\end{array}$ & {$[100]$} \\
\hline $\begin{array}{l}\text { Carbopol, aerosol, } \\
\text { veegum and } \\
\text { charcoal }\end{array}$ & $\begin{array}{l}\text { Mud of Lake Urmia } \\
\text { in Iran }\end{array}$ & Ointment & NA/Patients & $\begin{array}{c}\text { Pain relieved and decreased hs-CRP } \\
\text { and TNF- } a\end{array}$ & [101] \\
\hline $\begin{array}{l}\text { Epigallocatechin- } \\
\text { 3-gallate, gallic } \\
\text { acid, agallin and } \\
\text { methylxanthines }\end{array}$ & Camellia sinensisis & $\begin{array}{l}\text { Aqueous } \\
\text { solutions }\end{array}$ & NA/Patients & $\begin{array}{l}\text { Inhibited leukocytes, myeloperoxidase, } \\
\text { chondrocyte and ROS, protects DNA } \\
\text { damage and restores cartilage }\end{array}$ & [102] \\
\hline Naringin & Skimmia japonica & $\begin{array}{l}\text { Aqueous } \\
\text { solutions }\end{array}$ & $\begin{array}{l}\text { Surgical/ } \\
\text { Rats }\end{array}$ & $\begin{array}{l}\text { Decreased IL-1B, TNF- } a \text {, matrix- } \\
\text { metalloproteinase-13, free radicals } \\
\text { (NO) and ADAMTS-5 antibody }\end{array}$ & [103] \\
\hline Alpha-mangostinis & Garcinia mangostana & $\begin{array}{l}\text { Aqueous } \\
\text { solutions }\end{array}$ & IL-1B/Rats & $\begin{array}{c}\text { Prevents NO, PG-E2, COX2 and } \\
\text { metalloproteinases-(3,9 and 13) as } \\
\text { well inhibited NF-kB and p65 nuclear } \\
\text { translocation pathways }\end{array}$ & [104] \\
\hline Aucubin & Aucuba japonica & $\begin{array}{l}\text { Aqueous } \\
\text { solutions }\end{array}$ & NA/Patients & $\begin{array}{c}\text { Prevents NO, COX2 and } \\
\text { metalloproteinases-(3,9 and } 13) \text { as well } \\
\text { inhibited p65 nuclear translocation } \\
\text { pathway }\end{array}$ & {$[105,106]$} \\
\hline Anemonin & $\begin{array}{l}\text { Ranunculus } \\
\text { eschscholtzii }\end{array}$ & $\begin{array}{l}\text { Aqueous } \\
\text { solutions }\end{array}$ & $\begin{array}{l}\text { Surgical/ } \\
\text { Mouse }\end{array}$ & $\begin{array}{c}\text { Cartilage regeneration and decreases } \\
\text { metalloproteinase-13, ADAMTS-5, PG } \\
\text { and collagen X as well inhibited NF-KB } \\
\text { pathway }\end{array}$ & {$[107]$} \\
\hline $\begin{array}{l}\text { Salvianolic } \\
\text { acid-Bis }\end{array}$ & Salvia miltiorrhiza & $\begin{array}{l}\text { Intraperitoneal } \\
\text { saline solution }\end{array}$ & MIA/Mouse & $\begin{array}{c}\text { Inhibits NO, COX2, } \\
\text { metalloproteinases-13 and ADAMTS5 } \\
\text { and suppressed NK-KB and P65 nuclear } \\
\text { translocation pathways }\end{array}$ & [108] \\
\hline
\end{tabular}



PRECLINICAL STUDIES

\begin{tabular}{|c|c|c|c|c|c|}
\hline Therapeutics & Source & Formulation & $\begin{array}{c}\text { Causative } \\
\text { agent/Model }\end{array}$ & Therapeutic effects & Reference \\
\hline Curcuminoids & Curcuma longa & $\begin{array}{l}\text { Aqueous } \\
\text { solutions }\end{array}$ & MSU/Mice & $\begin{array}{l}\text { Reduces paw edema, normalizes lipid } \\
\text { peroxidation and renal markers. Inhibited } \\
\text { cytokines, purine metabolism and } \\
\text { enhances xanthine oxidase inhibitor }\end{array}$ & [109] \\
\hline Leaves & $\begin{array}{c}\text { Pistacia } \\
\text { integerrima }\end{array}$ & $\begin{array}{l}\text { Aqueous leaf } \\
\text { extract }\end{array}$ & Fructose/Mice & $\begin{array}{l}\text { Reduced uric acid level and promoted } \\
\text { antioxidants as well inhibits xanthine } \\
\text { oxidase }\end{array}$ & {$[110]$} \\
\hline Leaves & $\begin{array}{l}\text { Sparattosperma } \\
\text { leucanthum }\end{array}$ & $\begin{array}{l}\text { Ethyl acetate/ } \\
\text { methyl/aqueous } \\
\text { leaf extract }\end{array}$ & MSU/Mice & $\begin{array}{c}\text { Protects synovial cells damage, inhibits } \\
\text { xanthine oxidase and reduces uric acid } \\
\text { level }\end{array}$ & [48] \\
\hline $\begin{array}{l}\text { Leaves/ } \alpha \text { and } \\
\text { B Amyrins }\end{array}$ & Tabebuia roseoalba & $\begin{array}{c}\text { Ethanolic } \\
\text { leaves extract }\end{array}$ & MSU/Rats & $\begin{array}{c}\text { Reduces uric acid level, paw volume, IL- } \\
1, \mathrm{IL}-6, \mathrm{IL}-8 \text { and TNF-a. Suppressed NF-KB } \\
\text { and COX2 pathway }\end{array}$ & [111] \\
\hline Flower head & Helianthus annuus & $\begin{array}{l}\text { Aqueous extract } \\
\text { of head powder }\end{array}$ & MSU/Rats & $\begin{array}{c}\text { Reduces Paw edema, IL-10 and restored } \\
\text { cartilage, synovium deformation and cell } \\
\text { infiltration }\end{array}$ & [112] \\
\hline Piperine & Piper nigrum & $\begin{array}{l}\text { Aqueous } \\
\text { solution }\end{array}$ & MSU/Rats & $\begin{array}{l}\text { Restores the level of uric acid, lipid } \\
\text { peroxidation, lysosomal enzymes and } \\
\text { TNF-a }\end{array}$ & [40] \\
\hline Root powder & Withania somnifera & $\begin{array}{l}\text { Gum acacia } \\
\text { with root } \\
\text { powder }\end{array}$ & MSU/Rats & $\begin{array}{c}\text { Reduces the paw inflammation, lipid } \\
\text { peroxidation, lysosomal enzymes and } \\
\text { cytokines }\end{array}$ & [50] \\
\hline Triphala & $\begin{array}{l}\text { Emblica officinalis; } \\
\text { Terminalia chebula; } \\
\text { Terminalia bellirica } \\
\text { in the ratio of } 1: 1: 1\end{array}$ & $\begin{array}{l}\text { Aqueous } \\
\text { solutions }\end{array}$ & MSU/Rats & $\begin{array}{l}\text { Reduces the paw edema, lipid } \\
\text { peroxidation, lysosomal enzymes and } \\
\text { TNF- } \alpha \text { as well cartilage regneration }\end{array}$ & [113] \\
\hline Quercetin & $\begin{array}{l}\text { Beverages; } \\
\text { vegetables and } \\
\text { fruits }\end{array}$ & $\begin{array}{l}\text { Aqueous } \\
\text { solutions }\end{array}$ & MSU/Rats & $\begin{array}{c}\text { Reduces lysosomal enzymes and lipid } \\
\text { peroxidation in joints tissues. Also, } \\
\text { inhibited COX2, IL-1b, TNF-a, PGE2 and } \\
\text { NO and restored leukocyte infiltration in } \\
\text { joints }\end{array}$ & [114] \\
\hline Seed powder & $\begin{array}{l}\text { Cyamopsis } \\
\text { tetragonoloba }\end{array}$ & $\begin{array}{l}\text { Aqueous seed } \\
\text { extract }\end{array}$ & MSU/Rats & $\begin{array}{c}\text { Reduces renal markers and oxidative } \\
\text { stress in spleen and joint homogenate. } \\
\text { Importantly, protects bone erosion in } \\
\text { articular cartilage }\end{array}$ & [115] \\
\hline
\end{tabular}

infiltration in MSU-induced rats ${ }^{[111]}$. The plasma level of TNF- $\alpha$ is also reduced by piperine administration, whereas, in vitro study Polymorphonuclear Leucocyte (PNL) cell interaction is reduced by the piperine ${ }^{[40]}$. Withania somnifera root powder reduced the paw inflammation, lipid peroxidation, lysosomal enzymes and inflammatory responses in MSU-induced rats ${ }^{[50]}$. Triphala and Trikatu are made up of combinations of 3 different pants, which have been reported to increase the antioxidant level and paw histopathological analysis to restore joint erosion ${ }^{[112,113]}$. The quercetin decreased the pro-inflammatory mediators such as COX2, IL-1b, TNF- $\alpha$, PGE2 and NO. The study has reported that quercetin administration in MSU-induced rats has restored polymorphonuclear infiltration in the synovial layer, infiltration of leucocyte with vascular thrombosis and tissue necrosis in the joint histopathology ${ }^{[114]}$.

The therapeutic effect of natural products against rheumatoid arthritis includes, Withania somnifera has reduced the ankylosis and radiology score due to the cytokine (TNF- $\alpha$ ) inhibition that protects from disability ${ }^{[115]}$. Vitamin $\mathrm{P}$ has increased the antioxidant levels and reduced joint erosion and cartilage degradation, suppressing the NF- $\mathrm{B}$ pathway ${ }^{[16]}$. Milkvetch is proven to have antirheumatic activity by inhibiting serum osteoprotegerin in adjuvant-induced rats, which has also been reported to have suppressed NF- $\mathrm{B}$ p65 synovial by the immune-histochemical analysis $^{[117,118]}$. Tripterygium wilfordii root has been reported to reduce swelling, arthritic score and antibody titers in $3 \mathrm{w}^{[119,120]}$. Calotropis procera and Tamarixinin-A have restored the synovium hyperplasia, bone erosion and joint cartilage degradation in adjuvant and chemical-induced arthritis by inhibiting the NF- $\kappa \mathrm{B}$ signaling pathway ${ }^{[121,122]}$. Abrus precatorius recovered joint inflammation by blocked the COX2 pathway ${ }^{[123]}$. 
TABLE 3: ANTIARTHRITIC ACTIVITY OF NATURAL THERAPEUTICS ON RHEUMATOID ARTHRITIS AT CLINICAL/PRECLINICAL STUDIES

\begin{tabular}{|c|c|c|c|c|c|}
\hline Therapeutics & Source & Formulation & $\begin{array}{c}\text { Causative agent/ } \\
\text { Model }\end{array}$ & Therapeutic effects & Reference \\
\hline Root & $\begin{array}{l}\text { Withania } \\
\text { somnifera }\end{array}$ & $\begin{array}{l}\text { Aqueous root } \\
\text { extract }\end{array}$ & $\begin{array}{c}\text { Collagen and } \\
\text { adjuvant/Rats }\end{array}$ & $\begin{array}{l}\text { Reduces ankylosis, lipid peroxidation, } \\
\text { glycoprotein and cartilage regeneration }\end{array}$ & {$[116,117]$} \\
\hline Rutin & $\begin{array}{l}\text { Eucalyptus } \\
\text { tereticornis }\end{array}$ & $\begin{array}{l}\text { Aqueous } \\
\text { solution }\end{array}$ & Adjuvant/Rats & $\begin{array}{c}\text { Reduces joint erosion, cartilage } \\
\text { degradation, TNF- } \alpha \text { and IL-1B in NF-KB } \\
\text { pathway }\end{array}$ & [118] \\
\hline $\begin{array}{l}\text { Total } \\
\text { flavonoids }\end{array}$ & $\begin{array}{l}\text { Astragalus } \\
\text { propinquus }\end{array}$ & $\begin{array}{l}\text { Aqueous } \\
\text { solution }\end{array}$ & Adjuvant/Rats & $\begin{array}{l}\text { Reduces joint swelling and arthritic index, } \\
\text { restored BAX and BCL-2 and inhibited } \\
\text { PGE2, NF-KB and osteoprotegerin }\end{array}$ & [119] \\
\hline Root & $\begin{array}{l}\text { Tripterygium } \\
\text { wilfordii }\end{array}$ & $\begin{array}{l}\text { Aqueous root } \\
\text { extract }\end{array}$ & Collagen/Mice & $\begin{array}{c}\text { Reduces joint swelling, arthritic score } \\
\text { and antibody titers and restored cartilage } \\
\text { destruction }\end{array}$ & [120] \\
\hline Leaves & $\begin{array}{c}\text { Calotropis } \\
\text { procera }\end{array}$ & $\begin{array}{l}\text { Methanol leaf } \\
\text { extract }\end{array}$ & Adjuvant/Rats & $\begin{array}{l}\text { Increases antioxidants, decreases PGE2, } \\
\text { TNF- } \alpha \text { and lipid peroxidation and cartilage } \\
\text { regeneration }\end{array}$ & [121] \\
\hline Tamarixinin-A & Tamaricaceae & $\begin{array}{l}\text { Aqueous } \\
\text { solution }\end{array}$ & $\begin{array}{l}\text { Collagen and } \\
\text { adjuvant/Rats }\end{array}$ & $\begin{array}{l}\text { Restores synovium hyperplasia, bone } \\
\text { erosion and cartilage degradation, } \\
\text { decreases TNF-a, IL-6 and IL1-B and } \\
\text { inhibited p38 and NF-KB pathway }\end{array}$ & [122] \\
\hline Leaves & $\begin{array}{c}\text { Ziziphora } \\
\text { clinopodioides }\end{array}$ & $\begin{array}{l}\text { Aqueous leaf } \\
\text { extract }\end{array}$ & $\begin{array}{c}\text { Xylene and } \\
\text { carrageenan/Rats }\end{array}$ & $\begin{array}{l}\text { Reduces paw volume, pannus formation } \\
\text { and cartilage joint erosion and inhibited } \\
\text { autacoids }\end{array}$ & [123] \\
\hline Seeds & $\begin{array}{l}\text { Abrus } \\
\text { precatorius }\end{array}$ & $\begin{array}{c}\text { Ethanolic seed } \\
\text { extract }\end{array}$ & Adjuvant/Rats & $\begin{array}{c}\text { Prevents pannus formation, joint } \\
\text { inflammation and cartilage degradation } \\
\text { and inhibits cytokines and the COX2 } \\
\text { pathway }\end{array}$ & [124] \\
\hline Leaves & $\begin{array}{c}\text { Baccharis } \\
\text { genistelloides }\end{array}$ & $\begin{array}{c}\text { Aqueous leaves } \\
\text { extract }\end{array}$ & Collagen/Rats & $\begin{array}{l}\text { Prevents antigen presenting cells, } \\
\text { decreases cytokines, DNA damage and } \\
\text { articular cartilage degradation }\end{array}$ & [125] \\
\hline Bark & $\begin{array}{l}\text { Semecarpus } \\
\text { anacardiumis }\end{array}$ & $\begin{array}{c}\text { Aqueous bark } \\
\text { extract }\end{array}$ & Adjuvant/Rats & $\begin{array}{l}\text { Reduces lipid peroxidation, macrophages, } \\
\text { cytokines and restores joint damages }\end{array}$ & [126] \\
\hline
\end{tabular}

Aqueous extract of Semecarpus anacardium treated adjuvant-induced arthritis by inhibiting macrophages initiation and neutrophil infiltration. Collagen-induced arthritis found to have reduced the paw edema, antigenpresenting cells and DNA damage by the treatment of Baccharis genistelloides ${ }^{[24-135]}$.

\section{CONCLUSION}

Traditional medicine or natural therapeutics has been proved their potential antiarthritic activities to recover joint inflammation in various clinical and preclinical studies. Natural products and its active compounds are found to have significant activity when compared with chemical medications with no side effects. Our review has collectively covered the various factors/ agents causing or to induce joint inflammation such as osteoarthritis, gouty and rheumatoid arthritis. The chemicals that are used to cause arthritis and their mode of action have been discussed based on the report presented by researchers. Various researches have suggested that the natural product is beneficial compounds which treat arthritis without any side effects in preclinical studies. Many of the natural products with the essential ability against arthritis were not yet experimented and trails, which can be further study to understand its clear therapeutic mechanism against arthritis. This could be studied through in vivo, in silico and in vitro approaches.

\section{Acknowledgment:}

The authors are thankful to Vellore Institute of Technology (VIT) for providing the opportunity to carry out this article.

\section{Conflict of interests:}

The authors declared no conflicts of interest.

\section{REFERENCES}

1. Arthritis. National Institute of Arthritis and Musculoskeletal and Skin Diseases 2019.

2. Wollenhaupt J, Zeidler H. Undifferentiated arthritis and reactive arthritis. Curr Opin Rheumatol 1998;10(4):306-13.

3. Yasir M, Goyal A, Bansal P, Sonthalia S. Corticosteroid Adverse Effects. StatPearls 2021.

4. Ericson-Neilsen W, Kaye AD. Steroids: Pharmacology, Complications and Practice Delivery Issues. Ochsner J 2014;14(2):203-7.

5. Cronstein BN, Sunkureddi P. Mechanistic Aspects of 
Inflammation and Clinical Management of Inflammation in Acute Gouty Arthritis. J Clin Rheumatol 2013;19(1):19-29.

6. Dar RA, Shahnawaz M, Rasool S, Qazi PH. Natural product medicines: A literature update. J Phytopharm 2016;6(6):340-2.

7. HunterDJ,FelsonDT.Osteoarthritis. BMJ2006;332(7542):63942.

8. Takahashi I, Matsuzaki T, Kuroki H, Hoso M. Induction of osteoarthritis by injecting monosodium iodoacetate into the patellofemoral joint of an experimental rat model. PLoS one 2018;13.

9. Xu Q, Zhang Z, Sun W. Effect of Naringin on Monosodium Iodoacetate-Induced Osteoarthritis Pain in Rats. Med Sci Monit 2017;23:3746-51.

10. Heidari B. Knee osteoarthritis prevalence, risk factors, pathogenesis and features: Part I. Casp J Intern Med 2011;2(2):205-12.

11. Vina ER, Kwoh CK. Epidemiology of osteoarthritis: literature update. Curr Opin Rheumatol 2018;30(2):160-7.

12. Pal CP, Singh P, Chaturvedi S, Pruthi KK, Vij A. Epidemiology of knee osteoarthritis in India and related factors. Indian J Orthop 2016;50(5):518-22.

13. Johnson VL, Hunter DJ. The epidemiology of osteoarthritis. Best Pract Res Clin Rheumatol 2014;28(1):5-15.

14. Yasuda T. Cartilage destruction by matrix degradation products. Mod Rheumatol 2006;16(4):197-205.

15. Attur MG, Dave M, Akamatsu M, Katoh M, Amin AR. Osteoarthritis or osteoarthrosis: the definition of inflammation becomes a semantic issue in the genomic era of molecular medicine. Osteoarthritis Cartilage 2002;10(1):1-4.

16. Loeser RF. Molecular Mechanisms of Cartilage Destruction: Mechanics, Inflammatory Mediators and Aging Collide. Arthritis Rheum 2006;54(5):1357-60.

17. Patel DV, Sawant MG, Kaur G. Evaluation of anti-osteoarthritic activity of Vigna mungo in papain induced osteoarthritis model. Indian J Pharmacol 2015;47(1):59-64.

18. Martel-Pelletier J, Alaaeddine N, Pelletier JP. Cytokines and their role in the pathophysiology of osteoarthritis. Front Biosci 1999;4:D694-703.

19. Murat N, Karadam B, Ozkal S, Karatosun V, Gidener S. Quantification of papain-induced rat osteoarthritis in relation to time with the Mankin score. Acta Orthop Traumatol Turc 2007;41(3):233-7.

20. Little CB, Smith MM. Animal models of osteoarthritis. Curr Rheumatol Rev 2008;4:175-82.

21. Marker CL, Pomonis JD. The monosodium iodoacetate model of osteoarthritis pain in the rat. Methods Mol Biol 2012;851:239-48.

22. Bae KJ, Jeong JW, Choi CH, Won JY, Kim TG, Kim YR, et al. Antiosteoarthritic Effects of ChondroT in a Rat Model of Monosodium Iodoacetate-Induced Osteoarthritis. Evid Based Complement Alternat Med 2018;2018:8565132.

23. Moilanen LJ, Hämäläinen M, Lehtimäki L, Nieminen RM, Moilanen E. Urate Crystal Induced Inflammation and Joint Pain Are Reduced in Transient Receptor Potential Ankyrin 1 Deficient Mice-Potential Role for Transient Receptor Potential Ankyrin 1 in Gout. PLoS One 2015;10(2):e0117770.

24. Udo M, Muneta T, Tsuji K, Ozeki N, Nakagawa Y, Ohara T, et al. Monoiodoacetic acid induces arthritis and synovitis in rats in a dose and time dependent manner: proposed model-specific scoring systems. Osteoarthritis Cartilage 2016;24(7):1284-91.

25. Eid K, Thornhill TS, Glowacki J. Chondrocyte gene expression in osteoarthritis: Correlation with disease severity. J Orthop Res 2006;24(5):1062-8.
26. Jiménez Fernández D, Lamkanfi M. Inflammatory caspases: key regulators of inflammation and cell death. Biol Chem 2015;396(3):193-203.

27. Nirmal P, Koppikar S, Bhondave P, Narkhede A, Nagarkar $\mathrm{B}$, Kulkarni V, et al. Influence of six medicinal herbs on collagenase-induced osteoarthritis in rats. Am J Chin Med 2013;41(6):1407-25.

28. Kim JK, Park SW, Kang JW, Kim YJ, Lee SY, Shin J, et al. Effect of GCSB-5, a Herbal Formulation, on Monosodium Iodoacetate-Induced Osteoarthritis in Rats. Evid Based Complement Altern Med 2012;2012:730907.

29. Kuyinu EL, Narayanan G, Nair LS, Laurencin CT. Animal models of osteoarthritis: classification, update and measurement of outcomes. J Orthop Surg Res 2016;11.

30. Zhang W, Jones A, Doherty M. Does paracetamol (acetaminophen) reduce the pain of osteoarthritis?: A metaanalysis of randomised controlled trials. Ann Rheum Dis 2004;63(8):901-7.

31. Yoon E, Babar A, Choudhary M, Kutner M, Pyrsopoulos N. Acetaminophen-Induced Hepatotoxicity: A Comprehensive Update. J Clin Transl Hepatol 2016;4(2):131-42.

32. Fokunang CN, Fokunang ET, Frederick K, Ngameni B, Ngadjui B. Overview of non-steroidal anti-inflammatory drugs (nsaids) in resource limited countries. MOJ Toxicol 2018;4(1):5-13.

33. Wongrakpanich S, Wongrakpanich A, Melhado K, Rangaswami J. A Comprehensive Review of Non-Steroidal Anti-Inflammatory Drug Use in the Elderly. Aging Dis 2018;9(1):143-50.

34. Ayhan E, Kesmezacar H, Akgun I. Intraarticular injections (corticosteroid, hyaluronic acid, platelet rich plasma) for the knee osteoarthritis. World J Orthop 2014;5(3):351-61.

35. Yavuz U, Sökücü S, Albayrak A, Oztürk K. Efficacy comparisons of the intraarticular steroidal agents in the patients with knee osteoarthritis. Rheumatol Int 2012;32(11):3391-6.

36. Stein C, Baerwald C. Opioids for the treatment of arthritis pain. Expert Opin Pharmacother 2014;15(2):193-202.

37. Nakatani T. Opioid therapy and management of side effects associated with opioids. Gan To Kagaku Ryoho 2017;44(4):294-7.

38. Rymal E, Rizzolo D. Gout: A comprehensive review. JAAPA 2014;27(9):26-31.

39. Richette P, Bardin T. Gout. Lancet 2010;375(9711):318-28.

40. Sabina EP, Nagar S, Rasool M.A role of piperine on monosodium urate crystal-induced inflammation-an experimental model of gouty arthritis. Inflammation 2011;34(3):184-92.

41. An J, Yang HJ, Park K, Lee J, Kim BW. Reparatory and preventive effects of oriental herb extract mixture (OHEM) on hyperuricemia and gout. Food Sci Biotechnol 2010;19:517-24.

42. Harris MD, Siegel LB, Alloway JA. Gout and Hyperuricemia. Am Fam Physician 1999;59(4):925-34.

43. Neogi T, Jansen TLTA, Dalbeth N, Fransen J, Schumacher HR, Berendsen D, et al. 2015 Gout classification criteria: An American College of Rheumatology/European League Against Rheumatism collaborative initiative. Arthritis Rheumatol 2015;67(10):2557-68.

44. Ragab G, Elshahaly M, Bardin T. Gout: An old disease in new perspective-A review. J Adv Res 2017;8(5):495-511.

45. Kuo CF, Grainge MJ, Zhang W, Doherty M. Global epidemiology of gout: Prevalence, incidence and risk factors. Nat Rev Rheumatol 2015;11(11):649-62.

46. Saigal R, Agrawal A. Pathogenesis and Clinical Management of Gouty Arthritis. J Assoc Physicians India 2015;63(12):5663. 
47. Busso N, So A. Mechanisms of inflammation in gout. Arthritis Res Ther 2010;12(2):206.

48. Lemos Lima R de C, Ferrari FC, de Souza MR, de Sá Pereira BM, de Paula CA, Saúde-Guimarães DA. Effects of extracts of leaves from Sparattosperma leucanthum on hyperuricemia and gouty arthritis. J Ethnopharmacol 2015;161:194-9.

49. Udhaya Lavinya B, Bardhan I, Evan Prince S. Efficacy of CoenzymeQ10 in inhibiting monosodium urate crystal-induced inflammation in rats. Eur J Pharmacol 2016;791:589-94.

50. Rasool M, Varalakshmi P. Suppressive effect of Withania somnifera root powder on experimental gouty arthritis: An in vivo and in vitro study. Chem Biol Interact 2006;164(3):17480.

51. Schlesinger N, De Meulemeester M, Pikhlak A, Yücel AE, Richard D, Murphy V, et al. Canakinumab relieves symptoms of acute flares and improves health-related quality of life in patients with difficult-to-treat gouty arthritis by suppressing inflammation: results of a randomized, dose-ranging study. Arthritis Res Ther 2011;13(2):R53.

52. Eggebeen AT. Gout: an update. Am Fam Physician 2007;76(6):801-8.

53. Ong KL, Wu BJ, Cheung BMY, Barter PJ, Rye KA. Arthritis: its prevalence, risk factors and association with cardiovascular diseases in the United States, 1999 to 2008. Ann Epidemiol 2013;23(2):80-6.

54. Burmester GR, Pope JE. Novel treatment strategies in rheumatoid arthritis. Lancet 2017;389 (10086):2338-48.

55. Dinesh P, Rasool M. uPA/uPAR signaling in rheumatoid arthritis: Shedding light on its mechanism of action. Pharmacol Res 2018;134:31-9.

56. Majithia V, Geraci SA. Rheumatoid Arthritis: Diagnosis and Management. Am J Med 2007;120(11):936-9.

57. Gibofsky A. Overview of epidemiology, pathophysiology and diagnosis of rheumatoid arthritis. Am J Manag Care 2012; 18:S295-302.

58. $\mathrm{Xu} \mathrm{B}$, Lin J. Characteristics and risk factors of rheumatoid arthritis in the United States: an NHANES analysis. PeerJ 2017;5:e4035.

59. Hunter TM, Boytsov NN, Zhang X, Schroeder K, Michaud K, Araujo AB. Prevalence of rheumatoid arthritis in the United States adult population in healthcare claims databases, 20042014. Rheumatol Int 2017;37(9):1551-7.

60. Myasoedova E, Crowson CS, Kremers HM, Therneau TM, Gabriel SE. Is the incidence of rheumatoid arthritis rising? Results from Olmsted County, Minnesota, 1955-2007. Arthritis Rheum 2010;62(6):1576-82.

61. Yamanaka H, Sugiyama N, Inoue E, Taniguchi A, Momohara S. Estimates of the prevalence of and current treatment practices for rheumatoid arthritis in Japan using reimbursement data from health insurance societies and the IORRA cohort (I). Mod Rheumatol 2014;24(1):33-40.

62. Fazal SA, Khan M, Nishi SE, Alam F, Zarin N, Bari MT, et al. A clinical update and global economic burden of rheumatoid arthritis. Endocr Metab Immune Disord Drug Targets 2018;18(2):98-109.

63. Orr CK, Najm A, Young F, McGarry T, Biniecka M, Fearon U, et al. The utility and limitations of CRP, ESR and DAS28-CRP in appraising disease activity in rheumatoid arthritis. Front Med 2018;5.

64. Guo Q, Wang Y, Xu D, Nossent J, Pavlos NJ, Xu J. Rheumatoid arthritis: pathological mechanisms and modern pharmacologic therapies. Bone Res 2018;6:15.

65. Firestein GS, McInnes IB. Immunopathogenesis of Rheumatoid
Arthritis. Immunity 2017;46(2):183-96.

66. Smolen JS, Aletaha D, McInnes IB. Rheumatoid arthritis. Lancet 2016;388(10055):2023-2038.

67. Gaffen SL. The role of interleukin-17 in the pathogenesis of rheumatoid arthritis. Curr Rheumatol Rep 2009;11(5):365-70.

68. Udhaya Lavinya B, Sangeetha N, Manisha P, Ramkumar K, Kavitha M, Evan Prince Sabina. Virtual screening of peptidyl arginine deiminase type 4 inhibiting potential of chosen flavonoids. Res J Pharm Technol 2018;11:753-7.

69. Hu Y, Yang Y, Luo B. Evaluation of destruction in a collageninduced arthritis rat model: Bony spur formation. Exp Ther Med 2017;14(3):2563-7.

70. Miyoshi M, Liu S. Collagen-induced arthritis models. Methods Mol Biol 2018;1868:3-7.

71. Bevaart L, Vervoordeldonk MJ, Tak PP. Collagen-induced arthritis in mice. Methods Mol Biol 2010;602:181-92.

72. Murunikkara V, Pragasam SJ, Kodandaraman G, Sabina EP, Rasool M. Anti-inflammatory effect of piperine in adjuvantinduced arthritic rats-a biochemical approach. Inflammation 2012;35(4):1348-56.

73. Wang X, He X, Zhang CF, Guo CR, Wang CZ, Yuan CS. Antiarthritic effect of berberine on adjuvant-induced rheumatoid arthritis in rats. Biomed Pharmacother 2017;89:887-93.

74. Kamel KM, Gad AM, Mansour SM, Safar MM, Fawzy HM. Novel anti-arthritic mechanisms of polydatin in complete freund's adjuvant-induced arthritis in rats: Involvement of IL6, STAT-3, IL-17 and NF-кB. Inflammation 2018;41:1974-86.

75. Arab HH, El-Sawalhi MM. Carvedilol alleviates adjuvantinduced arthritis and subcutaneous air pouch edema: modulation of oxidative stress and inflammatory mediators. Toxicol Appl Pharmacol 2013;268(2):241-8.

76. Van Eden W, Waksman BH. Immune regulation in adjuvantinduced arthritis: possible implications for innovative therapeutic strategies in arthritis. Arthritis Rheum 2003;48(7):1788-96.

77. Chouk M, Bordy R, Moretto J, Tournier-Nappey M, Prati C, Wendling D, et al. SAT0102 Pristane-induced arthritis in dark agouti rat: a new animal model to study cardiovascular dysfunction in rheumatoid arthritis. Ann Rheum Dis 2018;77:913.

78. Patten C, Bush K, Rioja I, Morgan R, Wooley P, Trill J, et al. Characterization of pristane-induced arthritis, a murine model of chronic disease: response to antirheumatic agents, expression of joint cytokines and immunopathology. Arthritis Rheum 2004;50(10):3334-45.

79. Yau ACY, Holmdahl R. Rheumatoid arthritis: Identifying and characterising polymorphisms using rat models. Dis Model Mech 2016;9(10):1111-23.

80. Esser RE, Stimpson SA, Cromartie WJ, Schwab JH. Reactivation of streptococcal cell wall-induced arthritis by homologous and heterologous cell wall polymers. Arthritis Rheum 1985;28:1402-11.

81. Schrier DJ, Schimmer RC, Flory CM, Tung DK, Ward PA. Role of chemokines and cytokines in a reactivation model of arthritis in rats induced by injection with streptococcal cell walls. J Leukoc Biol 1998;63:359-63.

82. Rioja I, Clayton CL, Graham SJ, Life PF, Dickson MC. Gene expression profiles in the rat streptococcal cell wall-induced arthritis model identified using microarray analysis. Arthritis Res Ther 2004; 7:R101.

83. Crofford LJ. Use of NSAIDs in treating patients with arthritis. Arthritis Res Ther 2013;15:S2.

84. Clarke L, Kirwan J. Efficacy, safety and mechanism of action 
of modified-release prednisone in rheumatoid arthritis. Ther Adv Musculoskelet Dis 2012;4(3):159-66.

85. Haraoui B, Jovaisas A, Bensen WG, Faraawi R, Kelsall J, Dixit $\mathrm{S}$, et al. Use of corticosteroids in patients with rheumatoid arthritis treated with infliximab: Treatment implications based on a real-world Canadian population. RMD Open 2015;1(1):e000078.

86. Satyanarayanasetty D, Pawar K, Nadig P, Haran A. Multiple adverse effects of systemic corticosteroids: A case report. J Clin Diagn Res 2015;9(5):FD01-2.

87. Benjamin O, Lappin SL. Disease Modifying Anti-Rheumatic Drugs (DMARD). StatPearls 2018.

88. Aletaha D, Smolen JS. Diagnosis and management of rheumatoid arthritis: A review. JAMA 2018;320(13):1360-72.

89. Wang W, Zhou H, Liu L. Side effects of methotrexate therapy for rheumatoid arthritis: A systematic review. Eur J Med Chem 2018;158:502-16.

90. Joshi P, Dhaneshwar SS. An update on disease modifying antirheumatic drugs. Inflamm Allergy Drug Targets 2014;13(4):249-61.

91. Okoronkwo I, Onyia-pat JL, Okpala P, Agbo MA, Ndu A. Patterns of complementary and alternative medicine use, perceived benefits and adverse effects among adult users in Enugu Urban, Southeast Nigeria. Evid Based Complement Altern Med 2014;2014.

92. Poivre M, Duez P. Biological activity and toxicity of the Chinese herb Magnolia officinalis Rehder \& E. Wilson (Houpo) and its constituents. J Zhejiang Univ Sci B. 2017;18(3):194-214.

93. Mena P, Cirlini M, Tassotti M, Herrlinger KA, Dall'Asta C, Del Rio D. Phytochemical profiling of flavonoids, phenolic acids, terpenoids and volatile fraction of a Rosemary (Rosmarinus officinalis L.) Extract. Molecules 2016;21(11):1576.

94. Cory H, Passarelli S, Szeto J, Tamez M, Mattei J. The role of polyphenols in human health and food systems: A MiniReview. Front Nutr 2018;5:87.

95. Vauzour D, Rodriguez-Mateos A, Corona G, Oruna-Concha MJ, Spencer JPE. Polyphenols and human health: prevention of disease and mechanisms of action. Nutrients 2010;2(11):110631.

96. Simon JP, Prince SE. Natural remedies for non-steroidal anti-inflammatory drug-induced toxicity. J Appl Toxicol 2017;37(1):71-83.

97. Karimi A, Majlesi M, Rafieian-Kopaei M. Herbal versus synthetic drugs; beliefs and facts. J Nephropharmacol 2015;4(1):27-30.

98. Chen YJ, Tsai KS, Chan DC, Lan KC, Chen CF, Yang RS, et al. Honokiol, a low molecular weight natural product, prevents inflammatory response and cartilage matrix degradation in human osteoarthritis chondrocytes. J Orthop Res 2014;32(4):573-80.

99. Belcaro G, Cesarone MR, Dugall M, Pellegrini L, Ledda A, Grossi MG, et al. Product-evaluation registry of Meriva $^{\circledR}$, a curcumin-phosphatidylcholine complex, for the complementary management of osteoarthritis. Panminerva Med 2010;52:55-62.

100. Choi JH, Choi JH, Kim DY, Yoon JH, Youn HY, Yi JB, et al. Effects of SKI 306X, a new herbal agent, on proteoglycan degradation in cartilage explant culture and collagenaseinduced rabbit osteoarthritis model. Osteoarthritis Cartilage 2002;10(6):471-8.

101. Mahboob N, Sousan K, Shirzad A, Amir G, Mohammad V, Reza M, et al. The efficacy of a topical gel prepared using lake urmia mud in patients with knee osteoarthritis. J Altern
Complement Med 2009;15(11):1239-42.

102. Hashempur MH, Sadrneshin S, Mosavat SH, Ashraf A. Green tea (Camellia sinensis) for patients with knee osteoarthritis: A randomized open-label active-controlled clinical trial. Clin Nutr 2018;37(1):85-90.

103. Zhao Y, Li Z, Wang W, Zhang H, Chen J, Su P, et al. Naringin protects against cartilage destruction in osteoarthritis through repression of NF- $\kappa \mathrm{B}$ signaling pathway. Inflammation 2016;39(1):385-92.

104. Pan T, Wu D, Cai N, Chen R, Shi X, Li B, et al. Alpha-Mangostin protects rat articular chondrocytes against IL-1 $\beta$-induced inflammation and slows the progression of osteoarthritis in a rat model. Int Immunopharmacol 2017;52:34-43.

105. Wang SN, Xie GP, Qin CH, Chen YR, Zhang KR, Li X, et al. Aucubin prevents interleukin-1 beta induced inflammation and cartilage matrix degradation via inhibition of NF- $\kappa \mathrm{B}$ signaling pathway in rat articular chondrocytes. Int Immunopharmacol 2015;24(2):408-15.

106. Young IC, Chuang ST, Hsu CH, Sun YJ, Liu HC, Chen YS, et al. Protective effects of aucubin on osteoarthritic chondrocyte model induced by hydrogen peroxide and mechanical stimulus. BMC Complement Altern Med 2017;17(1):91.

107. Wang Z, Huang J, Zhou S, Luo F, Xu W, Wang Q, et al. Anemonin attenuates osteoarthritis progression through inhibiting the activation of IL- $1 \beta / \mathrm{NF}-\kappa \mathrm{B}$ pathway. J Cell Mol Med 2017;21(12):3231-43.

108. Lou Y, Wang C, Zheng W, Tang Q, Chen Y, Zhang X, et al. Salvianolic acid B inhibits IL- $1 \beta$-induced inflammatory cytokine production in human osteoarthritis chondrocytes and has a protective effect in a mouse osteoarthritis model. Int Immunopharmacol 2017;46:31-7.

109. Kiyani MM, Sohail MF, Shahnaz G, Rehman H, Akhtar MF, Nawaz I, et al. Evaluation of turmeric nanoparticles as antigout agent: Modernization of a traditional drug. Medicina 2019;55(1):10.

110. Yin J, Ren W, Huang X, Deng J, Li T, Yin Y. Potential mechanisms connecting purine metabolism and cancer therapy. Front Immunol 2018;9:1697.

111. Ferraz-Filha ZS, Michel Araújo MC de P, Ferrari FC, Dutra IPAR, Saúde-Guimarães DA. Tabebuia roseoalba: In vivo hypouricemic and anti-inflammatory effects of its ethanolic extract and constituents. Planta Med 2016;82(16):1395-402.

112. Li L, Teng M, Liu Y, Qu Y, Zhang Y, Lin F, et al. AntiGouty arthritis and antihyperuricemia effects of sunflower (Helianthus annuus) head extract in gouty and hyperuricemia animal models. BioMed Res Int 2017;2017:5852076.

113. Sabina EP, Rasool M. An in vivo and in vitro potential of Indian ayurvedic herbal formulation Triphala on experimental gouty arthritis in mice. Vascul Pharmacol 2008;48(1):14-20.

114. Huang J, Zhu M, Tao Y, Wang S, Chen J, Sun W, et al. Therapeutic properties of quercetin on monosodium urate crystal-induced inflammation in rat. J Pharm Pharmacol 2012;64(8):1119-27.

115. Peter SJ, Katturaja R, Namachivayam A, Nithyanandham S, Parthasarathy M, Sabina EP. Anti-inflammatory potential of the aqueous extract of Cyamopsis tetragonoloba against the MSU-induced arthritis in female Wistar albino rats. Asian Pac J Mol Biol Biotechnol 2020;28:1-12.

116. Rasool M, Varalakshmi P. Protective effect of Withania somnifera root powder in relation to lipid peroxidation, antioxidant status, glycoproteins and bone collagen on adjuvant-induced arthritis in rats. Fundam Clin Pharmacol 2007;21(2):157-64. 
117. Gupta A, Singh S. Evaluation of anti-inflammatory effect of Withania somnifera root on collagen-induced arthritis in rats. Pharm Biol 2014;52(3):308-20.

118. Sun CL, Wei J, Bi LQ. Rutin attenuates oxidative stress and proinflammatory cytokine level in adjuvant induced rheumatoid arthritis via inhibition of NF- $\kappa$ B. Pharmacology 2017;100:40-9.

119. Liu XY, Xu L, Wang Y, Li JX, Zhang Y, Zhang C, et al. Protective effects of total flavonoids of Astragalus against adjuvant-induced arthritis in rats by regulating OPG/RANKL/ NF- $\kappa$ B pathway. Int Immunopharmacol 2017;44:105-14.

120. Ushiro S, Ono M, Nakayama J, Fugiwara T, Komatsu Y, Sugimachi $\mathrm{K}$, et al. New nortriterpenoid isolated from anti-rheumatoid arthritic plant, Tripterygium wilfordii, modulates tumor growth and neovascularization. Int J Cancer 1997;72(4):657-63.

121. Kumar VL, Roy S. Calotropis procera latex extract affords protection against inflammation and oxidative stress in freund's complete adjuvant-induced monoarthritis in rats. Mediators Inflamm 2007;2007:47523.

122. Zhuang Y, Liu J, Ma P, Bai J, Ding Y, Yang H, et al. Tamarixinin A alleviates joint destruction of rheumatoid arthritis by blockade of MAPK and NF- $\kappa$ B activation. Front Pharmacol 2017;8.

123. Shabbir A, Batool SA, Basheer MI, Shahzad M, Sultana $\mathrm{K}$, Tareen RB, et al. Ziziphora clinopodioides ameliorated rheumatoid arthritis and inflammatory paw edema in different models of acute and chronic inflammation. Biomed Pharmacother 2018;97:1710-21.

124. Sudaroli M, Chatterjee TK. Evaluation of red and white seed extracts of Abrus precatorius Linn. against freunds complete adjuvant induced arthritis in rats. J Med Plants Res 2007;1:08694.

125. Coelho MGP, Reis PA, Gava VB, Marques PR, Gayer CR, Laranja GAT, et al. Anti-arthritic effect and subacute toxicological evaluation of Baccharis genistelloides aqueous extract. Toxicol Lett 2004;154:69-80.

126. Semalty M, Semalty A, Badola A, Joshi GP, Rawat MSM. Semecarpus anacardium Linn: A review. Pharmacogn Rev 2010;4:88-94.
127. Zhao Y, Li Z, Wang W, Zhang H, Chen J, Su P, et al. Naringin protects against cartilage destruction in osteoarthritis through repression of NF- $\kappa \mathrm{B}$ signaling pathway. Inflammation 2016;39(1):385-92.

128. Pan T, Wu D, Cai N, Chen R, Shi X, Li B, et al. Alpha-Mangostin protects rat articular chondrocytes against IL-1 $\beta$-induced inflammation and slows the progression of osteoarthritis in a rat model. Int Immunopharmacol 2017;52:34-43.

129. Wang Z, Huang J, Zhou S, Luo F, Xu W, Wang Q, et al. Anemonin attenuates osteoarthritis progression through inhibiting the activation of IL- $1 \beta / \mathrm{NF}-\kappa \mathrm{B}$ pathway. J Cell Mol Med 2017;21:3231-43.

130. Lou Y, Wang C, Zheng W, Tang Q, Chen Y, Zhang X, et al. Salvianolic acid B inhibits IL-1 $\beta$-induced inflammatory cytokine production in human osteoarthritis chondrocytes and has a protective effect in a mouse osteoarthritis model. Int Immunopharmacol 2017;46:31-7.

131. Yin J, Ren W, Huang X, Deng J, Li T, Yin Y. Potential mechanisms connecting purine metabolism and cancer therapy. Front Immunol 2018;9:1697.

132. Peter SJ, Katturaja R, Namachivayam A, Nithyanandham S, Parthasarathy M, Sabina EP. Anti-inflammatory potential of the aqueous extract of Cyamopsis tetragonoloba against the MSU-induced arthritis in female Wistar albino ratsJ. Asian Pac J Mol Biol Biotechnol 2020;28(3):1-12.

133. Rasool M, Varalakshmi P. Protective effect of Withania somnifera root powder in relation to lipid peroxidation, antioxidant status, glycoproteins and bone collagen on adjuvant-induced arthritis in rats. Fundam Clin Pharmacol 2007;21(2):157-64.

134. Shabbir A, Batool SA, Basheer MI, Shahzad M, Sultana $\mathrm{K}$, Tareen RB, et al. Ziziphora clinopodioides ameliorated rheumatoid arthritis and inflammatory paw edema in different models of acute and chronic inflammation. Biomed Pharmacother 2018;97:1710-21.

135. Semalty M, Semalty A, Badola A, Joshi GP, Rawat MSM. Semecarpus anacardium Linn.: A review. Pharmacogn Rev 2010;4(7):88-94. 